\title{
What is Migration History?
}

\author{
by C. Harzig and D. Hoerder, with D. Gabaccia \\ Malden, MA: Polity Press, 2009 \\ ISBN 978-0-7456-4336-6 \\ \$21.95, $200 \mathrm{pp}$.
}

\author{
Reviewed by Barry Edmonston \\ Department of Sociology and Population Research Group \\ University of Victoria \\ be@uvic.ca
}

There are relatively few books on the topic of migration history, and this brief volume provides a new contribution. It is written by three US professors of history (Dirk Hoerder's wife, Christiane Harzig, died before publication and Donna Gabaccia completed several unfinished sections). The volume is in a series of paperback books published by Polity Press entitled What is History?, intended as short introductions to topics such as medical history, military history, and global history.

This 181-page book includes six chapters, as well as lengthy notes and references. The first chapter provides a brief introduction, arguing that migration literature prior to the 1970 s was limited and failed to discuss adequately such topics as the migration of women and ethnic minorities. The second chapter is about 45 pages. This is the most useful chapter for students seeking a description of world migration history, as it provides an overview of migration, beginning with the early movements of Homo sapiens out of East Africa about 200,000 years ago and concluding with an informative summary of eight important current migration systems. Based on the authors' criticism of previous migration history, chapter 3 presents a critical review of migration theory, ranging from the work of E.G. Ravenstein in the 1880s to more recent literature on world systems theory and social network theory. Chapter 4 includes the authors' notion of a systems approach to migration, which is intended to offer a comprehensive theoretical framework for all factors influencing migration, as well as the effects of migration. As mentioned above, the authors believe that earlier migration literature did not focus adequate attention on several migration processes. Chapter 5 makes the case that recent migration literature has partially rectified earlier inadequacies. This chapter provides a discussion of recent work dealing with women and racial and ethnic minorities. The final, sixth chapter is a short discussion of three emerging important issues for migration study: global refugee movements, citizenship and political incorporation, and migrant identification.

As noted above, the most valuable reading in this book is chapter 2's summary of world migration history. Although this chapter could serve as supplementary reading for undergraduate students, its errors and a lack of a theoretical perspective makes it a poor 
choice for assigned reading. In spite of frequently interesting descriptions of the events, dates, and location of migration, there is little discussion of the migration processes themselves. Inclusion of an ecological perspective, such as illustrated in Amos Hawley's classic volume Urban Society (Hawley 1971), and other frameworks, are needed to help students understand why and how these social processes developed. As it stands, the second chapter is too much a recitation of "facts." For example, the authors stress that European dominance in the post-1500 period was primarily economic, with accumulation of wealth in core countries at the expense of the colonial periphery. They emphasize a single, narrow process, whereas an ecological perspective would argue that there are several social centripetal processes - including military, religious, and political, as well as economicthat were associated with increasing European dominance.

At times, the book stumbles. The authors sometimes make exaggerated claims. The introduction of mechanized agriculture in the late 1800s in Argentina, Australia, Canada, and the United States did not cause world grain prices to collapse as claimed (p. 41). To be sure, mechanized agriculture had disruptive effects, increased the supply of tradable world grains, and lowered market prices for some grains, but it did not cause overall global grain prices to collapse. Other statements by the authors are inaccurate. In describing employment shifts in the late 1800s and early 1900s, they state that industrialization reduced the demand for skilled workers and increased the need for unskilled men and women (p. 55). In fact, the job skills of workers increased over time in association with industrialization.

As another example, the authors state that Canada and the United States removed national-based "race" restrictions (some scholars would undoubtedly question the authors' equation of nationality with race) on immigration in the $1960 \mathrm{~s}$, and moved to a selection system based on family and employment qualifications. It is incorrect, however, to state that Canada and the United States only select immigrants with "merit systems based on skills and capabilities" (p. 49). This is particularly wrong for the United States, given that the majority of immigrants admitted to the US in recent years are admitted under family reunification categories (for example, in 2001, 70 per cent were family reunification immigrants). While most immigrants admitted by Canada are economic immigrants, almost 30 per cent admitted in 2006 were family reunification immigrants.

The exposition also poses problems for readers. The authors sometimes refer to processes or theories without explaining them. For instance, the meaning of this sentence is unclear: "In countries which, since the mid-1960s, introduced rigorous selection regimes for in-migration, market forces and policies interact beyond what labour market theory may explain" (p. 78). What market forces? What policies? And what does the reference to "beyond labour market theory" mean? Another example illustrates the difficulty that a reader will have understanding the exposition: "Migration research as (historical) anthropology is concerned with the 'spaces of agency' created by mobile people within existing-evolving structures” (p. 79). One sympathizes with any professor who is asked by students to explain these sentences.

In conclusion, one regrets that this short book is neither an accessible history of migration that might be suitable for undergraduate students nor an adequate historiography of migration history that might be useful for graduate demography students. Better options include Patrick Manning's Migration in World History (Manning 2005) for undergraduate students in population courses, and for graduate students, Robin Cohen's edited 
volume The Cambridge Survey of World Migration (Cohen 1995) provides an impressive collection of well-researched essays on many topics in migration history.

\section{References}

Cohen, R. (ed.). 1995. The Cambridge Survey of World Migration. Cambridge (UK)-New York: Cambridge University Press. (available at http://books.google.com/ books?id=YbzsBPuhyggC\&hl=en)

Hawley, A. 1971. Urban Society: An Ecological Approach. New York: Ronald Press Co. Manning, P. 2005. Migration in World History. Themes in World History Series. Milton Park (UK)-New York: Routledge. 